\title{
Estimation of Energy Efficiency for Hydropower Generator
}

\author{
Sim Sy Yi, Goh Hui Hwang, Ronny Wong Hoe Gi, Mohd Muzaffar Bin Zahar, Goh Kai Chen, \\ Ling Chin Wan, Sim Gia Yi
}

\begin{abstract}
Electrical energy is getting more important in our daily life. With the coming development of the Sarawak Corridor of Renewable Energy (SCORE), hydropower plant is getting more interesting to face the demand on the domestic usage. Electrical energy can be used to carry out our daily routine. Small hydropower been very adaptive solution for rural area. Hence, this paper shows the estimation of energy efficiency for hydropower generator for Belawai river located at Sarawak. Excess rainfall hyetograph and direct runoff hydrograph been use to evaluate efficiency of the power generation based on river flow. Result show river flow strength depend on the rainfall which is about $38.56 \%$ of efficiency and other environmental factors which will affect the efficiency of the converter.
\end{abstract}

Index Terms: hydropower, hyetograph, hydrograph.

\section{INTRODUCTION}

In Malaysia, the on-grid network is mostly supplying electricity to urban area in Malaysia. Mostly, on grid system uses an overhead transmission system to transmit electricity to another area. In terms of the economy, it is not worthy to build an overhead transmission to all the villages in Sarawak. It will cost a huge amount of money just to build a transmission system to connect the generator station with all the users in different areas. However, rural area mostly facing no reliable energy source [1]. Sarawak is covered with many rivers which have very high potential to generate hydroelectricity for local people [2]. Small hydropower plants are usually ranging from $100 \mathrm{~kW}$ till $1000 \mathrm{~kW}$. A micro hydropower plant is normally in the range of $5 \mathrm{~kW}$ to $100 \mathrm{~kW}$. The smallest hydropower plant is Pico Hydro, which under $5 \mathrm{~kW}$. However, some of the rural areas in Malaysia are still not available with electricity supply.

Revised Manuscript Received on August 18, 2019

Sim Sy Yi, Faculty of Engineering Technology, Universiti Tun Hussien Onn Malaysia, Parit Raja, 86400 Batu Pahat, Johor.

Goh Hui Hwang, Faculty of Electrical \& Electronic Engineering, Universiti Tun Hussien Onn Malaysia, Parit Raja, 86400 Batu Pahat, Johor.

Ronny Wonng Hoe Gi, Faculty of Electrical \& Electronic Engineering, Universiti Tun Hussien Onn Malaysia, Parit Raja, 86400 Batu Pahat, Johor.

Mohd Muzaffar Bin Zahar, Center for Diploma Studies, Faculty of Electrical Engineering, Universiti Tun Hussien Onn Malaysia, Parit Raja, 86400 Batu Pahat, Johor.

Goh Kai Chen, Faculty of Technology Management \& Business, Universiti Tun Hussein Onn Malaysia, Parit Raja, Batu Pahat, Johor, Malaysia.

Ling Chin Wan, Faculty of Electrical \& Electronic Engineering, Universiti Tun Hussien Onn Malaysia, Parit Raja, 86400 Batu Pahat, Johor.

Sim Ga Yi, Faculty of Electrical \& Electronic Engineering, Universiti Tun Hussien Onn Malaysia, Parit Raja, 86400 Batu Pahat, Johor.
They usually use petrol or diesel generators to generate electricity for domestic usage. According to Renewable \& Appropriate Energy Laboratory (RAEL) report, the electricity from diesel effectively will cost about RM 2.24 per $\mathrm{kWh}$. If compared to domestic electricity tariff from Sarawak Energy Berhad (SEB) is around RM0.31 per kWh, it is much more expensive according to the local report [3]. Furthermore, a generator set is quite expensive equipment which most of the villages cannot afford to purchase it. It also needs a huge transportation fee to transfer the machine to the users. On the other hand, some of the villages are hardly accessible by road. Thus, it needs a long time to transfer the source. In rural area, local villages are located next to the river. Boat and water transportation remain the major mode of transportation system. If the source of the generator is not provided in time, the electricity cannot be produced. This will affect the daily life of the local people. This paper will focus on the percentage efficient of rainfall to generate electricity of Belawai river.

\section{Belawai River}

Belawai river is located at latitude $2^{\circ} 12^{\prime} 14.4^{\prime \prime}$ North and longitude $111^{\circ} 14^{\prime} 59.8^{\prime \prime}$ East nearby Mukah district area in Sarawak. The river is located at the downstream which rich in mangrove forest. Hence, the selection of turbine for small hydropower generation is critical to avoid the various solid object which may in contact with turbine.

Belawai river the target for this research and the data collection is based on the data provide by the Department of Meteorologi Sarawak.

\section{Excess Rainfall Hyetograph AND Direct RUNOFF HYDROGRAPH}

Rainfall hyetograph is used to present the relationship between rainfall intensity over time in graphical methods. Hyetograph play in important role in the estimation of total rainfall of specific period. The data also useful in storm prediction by tracking the rainfall intensity and predict floods.

Direct runoff hereby means the data range is only the surface runoff where the amount of water flow from land through river or steam. Hydrograph is a graphical plot discharge of a natural stream or river versus time.

Excess rainfall and direct run off can be calculated as in (1) and (2) [4].

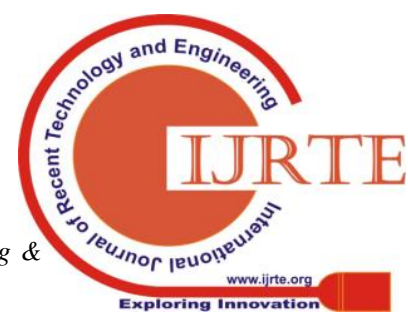


Excess rainfall $=$ Observed rainfall - Abstraction

Direct runoff $=$ Observed stream flow - Base flow

Depth of direct runoff can be calculated in Eq. 3 [2, 3]:

$$
\mathrm{r}_{d}=\sum_{m=1}^{M} R_{m}-\varnothing \Delta t
$$

where,

$R_{m}$ is the observed rainfall in time

$r_{d}$ is the depths of direct runoff (meter)

$\emptyset$ is the constant rate of abstractions ( $\mathrm{cm} /$ month)

$\mathrm{t}=$ time interval in monthly

The volume $V_{d}$ and depth of direct runoff $r_{d}$ can be calculated by using (4) and (5).

$$
\begin{aligned}
V_{d} & =\sum_{m=1}^{M} Q_{n} \Delta t \\
r_{d} & =\frac{v_{d}}{\text { watershed area }}
\end{aligned}
$$

where,

$V_{d}$ is the volume of the stream flow $\left(\mathrm{m}^{3}\right)$

$Q_{n}$ is the discharge rate of the stream flow $\left(\mathrm{m}^{3} / \mathrm{s}\right)$

$\Delta \mathrm{t}$ is the time interval (s)

Watershed area is the land that captures rainfall to the river $\left(m^{2}\right)$

\section{A. Estimate the rate of rainfall abstraction of infiltration and surface storage in the watershed}

Equation 3 will be applied with substitute value of $r_{d}$ from (5). The abstraction rate $\emptyset$, and the number of nonzero pulses of the excess rainfall $\mathrm{M}$, are found by trial and error [5]. The value of the abstraction rate $\emptyset$, need into be in found until it is positive value and greater than all the rainfall pulses outside of the assumed to contribute to direct runoff. At end of the result, the excess rainfall hyetograph $(\mathrm{ERH})$ value should be the same with the direct runoff depth, $r_{d}$.

\section{B. Estimate the efficient of rainfall to the generate electricity energy}

Efficient of rainfall can be calculated by comparing the excess rainfall data with the monthly rainfall data. It can be expressed in (6) [6]:

$$
\text { Efficient of rainfall }=\frac{\text { excess rainfall }}{\text { average monthly rainfall }} \times 100 \%
$$

\section{DATA AND ANALYSIS}

The result obtain is based on the data provided from Department of Meteortologi Sarawak. The data set is based on the year 2014 from January to December.

TABLE I.

THE INTENSITY OF RAINDROP IN YEAR 2014

\begin{tabular}{|c|c|c|c|c|c|}
\hline \multirow{2}{*}{$\begin{array}{c}\text { Time } \\
\text { (month) }\end{array}$} & \multirow{2}{*}{$\begin{array}{c}\text { Rainfall } \\
(\mathrm{mm})\end{array}$} & Cumulative & \multicolumn{3}{|c|}{ Running Totals } \\
\cline { 4 - 6 } & Rainfall(mm) & 1 month & 3month & 4month \\
\hline $2014-1$ & 566.3 & 566.3 & & & \\
\hline $2014-2$ & 38.2 & 604.5 & 38.2 & & \\
\hline $2014-3$ & 157.8 & 762.3 & 157.8 & & \\
\hline $2014-4$ & 174.2 & 936.5 & 174.2 & 370.2 & \\
\hline $2014-5$ & 179.4 & 1115.9 & 179.4 & 511.4 & 549.6 \\
\hline $2014-6$ & 36.7 & 1152.6 & 36.7 & 390.3 & 548.1 \\
\hline $2014-7$ & 91.8 & 1244.4 & 91.8 & 307.9 & 482.1 \\
\hline $2014-8$ & 438.8 & 1683.2 & 438.8 & 567.3 & 746.7 \\
\hline $2014-9$ & 313.2 & 1996.4 & 313.2 & 843.8 & 880.5 \\
\hline $2014-10$ & 241.4 & 2237.8 & 241.4 & 993.4 & 1085.2 \\
\hline $2014-11$ & 520 & 2757.8 & 520.0 & 1074.6 & 1513.4 \\
\hline $2014-12$ & 584.6 & 3342.4 & 584.6 & 1346.0 & 1659.2 \\
\hline $\begin{array}{c}\text { Max } \\
\text { depth }\end{array}$ & 584.6 & & 584.6 & 1346 & 1659.2 \\
\hline & intensity & per month & 584.6 & 448.7 & 414.8 \\
\hline
\end{tabular}

From Table 1 and Fig. 1, it can clearly see that the rainfall in between July and August and also November and December has the higher gradient if compare to another month period. It can be said that the intensity rainfall in that period is the more that other time.

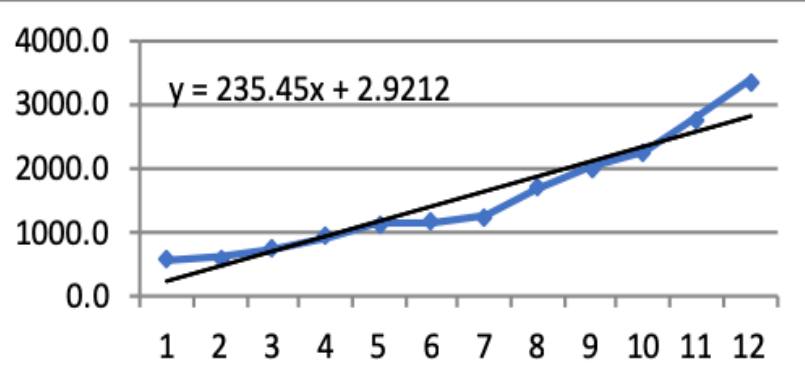

Fig 1. The intensity of rainfall 
TABLE II.

THE SUMMARY OF EXCESS RAINFALL HYETOGRAPH(ERH) AND DIRECT RUNOFF HYDROGRAPH(DRH)

\begin{tabular}{|c|c|c|c|c|c|c|}
\hline $\begin{array}{l}\text { Time } \\
\text { (month) }\end{array}$ & $\begin{array}{l}\text { Rainfall } \\
(\mathbf{m m})\end{array}$ & $\begin{array}{l}\text { Stream Flow } \\
\left(\mathrm{m}^{3} / \mathrm{s}\right)\end{array}$ & $\begin{array}{l}\text { abstraction } \\
(\mathbf{m m})\end{array}$ & $\begin{array}{l}\text { ERH } \\
(\mathbf{m m}) \\
\end{array}$ & $\begin{array}{l}\text { Baseflow } \\
\left(\mathrm{m}^{3} / \mathrm{s}\right)\end{array}$ & $\begin{array}{l}\text { DRH } \\
\left(\mathrm{m}^{3} / \mathbf{s}\right) \\
\end{array}$ \\
\hline 2014-1 & 566.3 & 1337.479 & 228.690 & 337.6 & 11.3267 & 1326.153 \\
\hline 2014-2 & 38.2 & 1316.266 & 228.690 & 0.0 & 11.3267 & 1304.939 \\
\hline 2014-3 & 157.8 & 1296.509 & 228.690 & 0.0 & 11.3267 & 1285.182 \\
\hline 2014-4 & 174.2 & 1296.315 & 228.690 & 0.0 & 11.3267 & 1284.988 \\
\hline $2014-5$ & 179.4 & 1313.644 & 228.690 & 0.0 & 11.3267 & 1302.318 \\
\hline 2014-6 & 36.7 & 1333.671 & 228.690 & 0.0 & 11.3267 & 1322.344 \\
\hline 2014-7 & 91.8 & 1337.479 & 228.690 & 0.0 & 11.3267 & 1326.153 \\
\hline $2014-8$ & 438.8 & 1311.544 & 228.690 & 210.1 & 11.3267 & 1300.217 \\
\hline $2014-9$ & 313.2 & 1293.859 & 228.690 & 84.5 & 11.3267 & 1282.532 \\
\hline 2014-10 & 241.4 & 1290.981 & 228.690 & 12.7 & 11.3267 & 1279.654 \\
\hline 2014-11 & 520 & 1314.308 & 228.690 & 291.3 & 11.3267 & 1302.981 \\
\hline 2014-12 & 584.6 & 1328.901 & 228.690 & 355.9 & 11.3267 & 1317.574 \\
\hline Total & 3342.4 & 15770.955 & & 1292.1 & & 15635.035 \\
\hline
\end{tabular}

\section{Combination Data on ERH $(\mathrm{mm})$ \& DRH $(\mathrm{m} 3 / \mathrm{s})$}

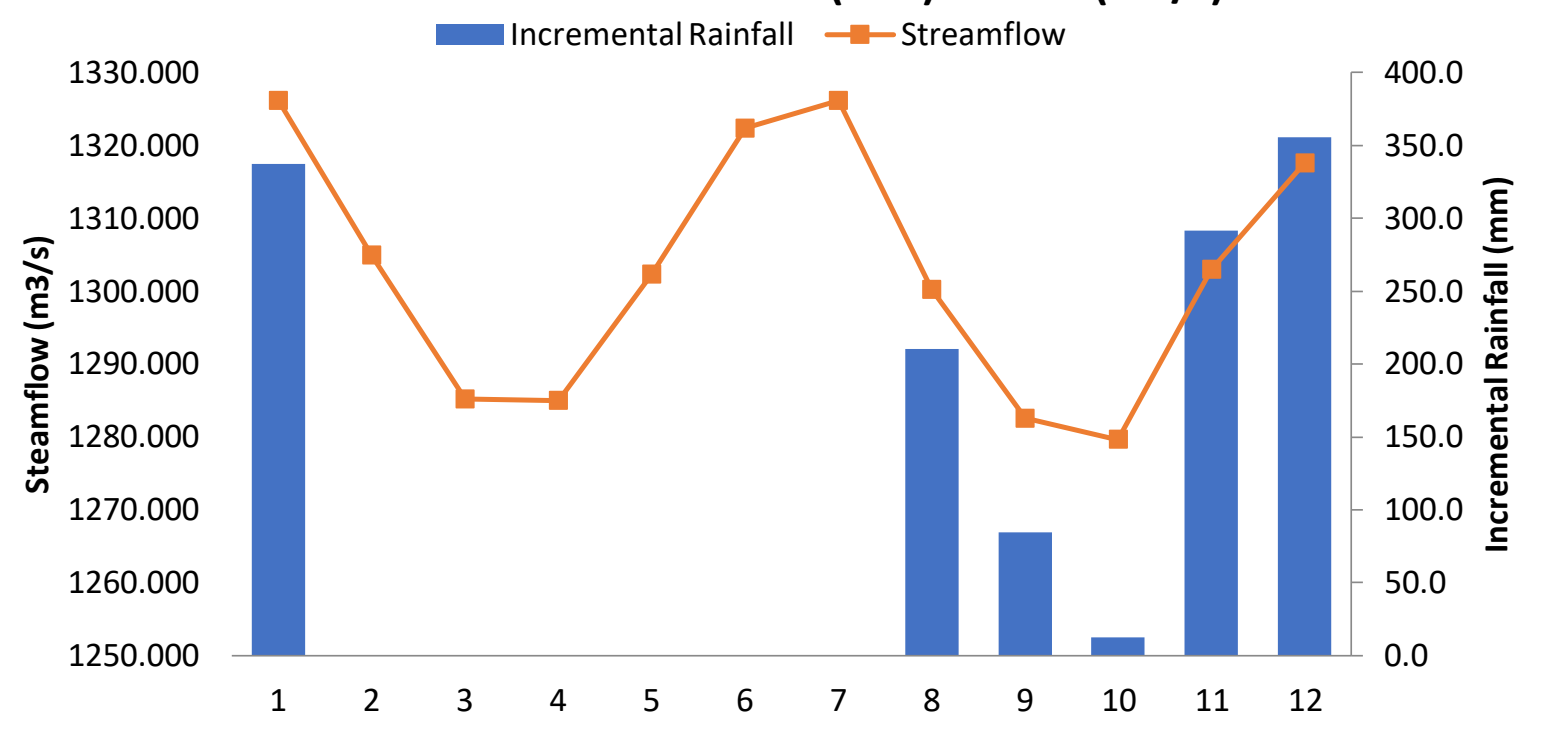

Fig 2. Graph on Excess Rainfall Hyetograph(ERH) and Direct runoff Hydrograph(DRH)in monthly

The ERH and DRH can be found by following steps:

Step 1: Decide the Base flow.

In Table 7, the base flow is set as 400cfs which is nearly about $11.3267 \mathrm{~m}^{\wedge} 3 / \mathrm{s}$.

Step 2: Find the Direct runoff Hydrograph (DRH) and total value of direct runoff hydrograph (DRH)

DRH can be calculated by subtraction of stream flow $\mathrm{m}^{\wedge} 3 / \mathrm{s}$ to the base flow. For example,

$1337.479 \mathrm{~m}^{\wedge} 3 / \mathrm{s}-11.3267 \mathrm{~m}^{\wedge} 3 / \mathrm{s}=1326.153 \mathrm{~m}^{\wedge} 3 / \mathrm{s}$.

Step 3: Find the volume in monthly

$15635.035 \mathrm{~m}^{\wedge} 3 / \mathrm{s}$ X 30 (month) X 24(hour) X 60(minutes) $\mathrm{X} 60$ (seconds) $=40,526,010,125 \mathrm{~m}^{\wedge} 3$
Step 4: Find the direct runoff depth, $\mathrm{r}_{-} \mathrm{d}(\mathrm{mm})$

Watershed area can be calculated as follows:

Since the Belawai River is one of the branches of the Rejang River, therefore, the watershed area will include all the Rejang River area that captures rainfall to the river. From the map, it is about $25 \%$ of the Sarawak size. Thus, the watershed area can be calculated as:

$125,450,000,000 \quad \mathrm{~m}^{\wedge} 2$ (Sarawak area) $\mathrm{X} 25 \%=$ $31,362,500,000 \mathrm{~m}^{\wedge} 2$.

Thus, the depth of direct runoff is:

r_d $=$ v_d (watershed area)

r_d $=40,526,010,125 \quad \mathrm{~m}^{\wedge} 3 \quad 131,362,500,000 \quad \mathrm{~m}^{\wedge} 2=$ $1.29218 \mathrm{~m}$

Convert to millimeter is $1292.18 \mathrm{~mm}$. 
Step 5: Find the abstraction

As we obtained the r_d will be $1292.16 \mathrm{~mm}$. Thus, we can calculate the abstraction value, $\varnothing$.

$$
\begin{aligned}
& \varnothing=\left(\sum \text { Rm }-\mathrm{rd}\right) / \Delta \mathrm{t} \\
& \text { M1 } \quad \varnothing=[(584.6)-1292.18] / 1 \\
&=-707.58 \mathrm{~mm} \\
& \text { M2 } \quad \varnothing=[(584.6+566.3)-1292.18] / 2 \\
&=-70.64 \mathrm{~mm} \\
& \text { M3 } \quad \varnothing=[(584.6+566.3+520)-1292.18] / 3 \\
&=126.24 \mathrm{~mm} \\
& \text { M4 } \quad \varnothing=[(584.6+566.3+520+438.8)-1292.18] / 4 \\
&=204.38 \mathrm{~mm} \\
& \text { M5 } \quad \varnothing=[(584.6+566.3+520+438.8+313.2)-1292.18] / 5 \\
&=226.14 \mathrm{~mm} \\
& \text { M6 } \quad \varnothing=[(584.6+566.3+520+438.8+313.2+241.4)-1292 \\
&.18] / 6 \\
&=228.69 \mathrm{~mm}
\end{aligned}
$$

\begin{tabular}{|c|c|c|c|c|c|}
\hline & $\mathbf{r d}(\mathbf{m m})$ & $\begin{array}{l}\left(\sum \mathbf{R m}\right) \\
\mathbf{m m}\end{array}$ & $\begin{array}{l}\Delta t \\
\text { (month) }\end{array}$ & $\emptyset(\mathbf{m m})$, & Accepted? \\
\hline M1 & 1292.18 & 584.6 & 1 & -707.58 & $\mathrm{NO}$ \\
\hline M2 & 1292.18 & 1150.9 & 2 & -70.64 & NO \\
\hline M3 & 1292.18 & 1670.9 & 3 & 126.24 & NO \\
\hline M4 & 1292.18 & 2109.7 & 4 & 204.38 & NO \\
\hline M5 & 1292.18 & 2422.9 & 5 & 226.14 & NO \\
\hline M6 & 1292.18 & 2664.3 & 6 & 228.69 & YES \\
\hline
\end{tabular}

TABLE III.

SUMMARY OF THE TRIAL AND ERROR TO FIND THE ABSTRACTION VALUE, $\varnothing$

Thus, from Table 3, we get the abstraction value with $228.69 \mathrm{~mm}$. The abstraction value should not in negative value and should greater than all of the rainfall pulses outside of the assumed.

Step 6: Find the ERH

ERH can be calculated by:

$\mathrm{ERH}=$ observed rainfall - abstraction, $\varnothing$ which had showed in Table 2 column of ERH.

From the data, we obtained the total ERH value will be $1292.1 \mathrm{~mm}$. The total ERH value is almost same with the depth of direct runoff value. The value of the ERH is compared with the depth of the direct runoff value.

$(1292.18-1292.1) / 1292.18 \times 100 \%=0.00619 \%$

Thus, the result is accepted with $0.00619 \%$ different error.

Step 7: Calculate the efficient of rainfall

Efficient of rainfall $=(($ Excess rainfall $)) /(($ average monthly rainfall $)) \times 100 \%=(1292.1 \mathrm{~mm} / 3342.4 \mathrm{~mm}) \mathrm{X}$ $100 \%=38.658 \%$.

\section{CONCLUSION}

At end of this research, the condition of the Belawai River is suitable to generate kinetic energy which can be used as to produce electrical energy for local rural usage. Vertical type converter had been chosen to generate electrical energy due to the Belawai River flow rate is less than $0.5 \mathrm{~m} / \mathrm{s}$ [4]. River flow strength will depend on the rainfall which is about $38.56 \%$ of efficiency and other environmental factors which will affect the efficiency of the converter.

\section{ACKNOWLEDGEMENT}

The authors would like to thank the Ministry of Science, Technology and Innovation, Malaysia (MOSTI), and the Office for Research, Innovation, Commercialization, Consultancy Management (ORICC), Universiti Tun Hussein Onn Malaysia (UTHM) for financially supporting this research under the Science Fund grant No.S023 and IGSP Vot. U242.

\section{REFERENCES}

1. Goh, H. H., Kok, B. C., Baharom, M. N. R., Ishak, M. T., Goh, K. C., \& Lee, S. W. (2014). Structural equation and system dynamic model of islanded wind power grids evaluation (Doctoral dissertation, Universiti Tun Hussein Onn Malaysia).

2. Teo, K. T. K., Goh, H. H., Chua, B. L., Tang, S. K., \& Tan, M. K. (2013, April). Modelling and optimisation of stand alone power generation at rural area. In ICCE-China Workshop (ICCE-China), 2013 IEEE (pp. 51-56). IEEE.

3. Shirley. Rebekah, Sustainable Rural Energy in the Baram River Basin, Sarawak, Malaysia, Berkeley, Renewable and appropriate Energy Laboratory (RAEL) \&Energy and Resources Group and Goldman School of Public Policy, Jan 2014

4. K Subramanya Engineering Hydrology 3rd edition, The McGraw Hill Companies pp 101-111 \& pp 139-143.

5. Ven Te Chow, DavidR.Maidment and Larry W.Mays,(1988) Applied Hydrology ,McGraw-Hill Book Co. pp. 75-77 and 135-140

6. G.Adedokun, J.A.OLadosu and T.K Ajiboye (2013) Small Hydro Power Potential Capacity Estimation for Provision of Rural Electricity in Nigeria ACTA TECHNIcA CORVINENSIS, Bulletin of Engineering

\section{AUTHORS PROFILE}

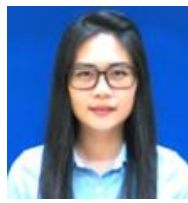

Sim Sy Yi received the B.Eng degree in electrical engineering and $\mathrm{Ph} . \mathrm{D}$ degree in electrical from Universiti Tun Hussein Onn Malaysia (UTHM) in 2012 and 2016, respectively. Currently, she is a lecturer in Universiti Tun Hussein Onn Malaysia (UTHM). Her current research interests include of power electronic, artificial intelligent, renewable energy and power system.

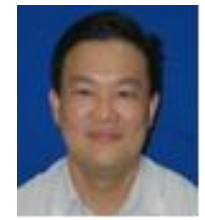

Goh Hui Hwang received his B.Eng degree in electrical engineering and M.Eng degree in electrical from Universiti Teknology Malaysia (UTM) in 1998 and 2003, respectively. Then he received his $\mathrm{Ph} . \mathrm{D}$ degree in Universiti Teknologi Malaysia (UTM) in 2007. Currently, he is an associate professor in Universiti Tun Hussein Onn Malaysia (UTHM). His current research interests include of power system, artificial intelligent, renewable energy and renewable energy policies.

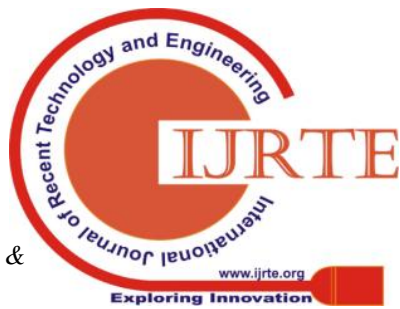


Ronny Wong Hoe Gi received his B.Eng. (Electrical Engineering) from Universiti Tun Hussien Onn Malaysia (UTHM) in 2016.

Mohd Muzaffar Bin Zahar received his B.Sc. in Electrical Engineering (Mechatronics) from Universiti Teknologi Malaysia, Skudai, Malaysia in 2008 and graduated in same university with a Master in Electrical Engineering in 2013 under the supervision of Dr. Sharifah Hafizah Syed Ariffin. He is now a lecturer at the Industrial Training Institute of Marang.

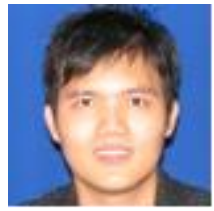

Goh Kai Chen received the B.Eng degree in science and M.Eng degree in science (construction management) from Universiti Teknology Malaysia (UTM) in 2005 and 2006, respectively. Then he received his Ph.D degree in Queensland University of Technology in 2011. Currently, he is an associate professor in Universiti Tun Hussein Onn Malaysia (UTHM). His current research interests include of environment sustainable construction

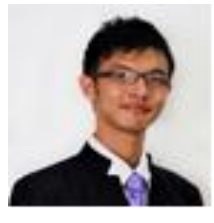

Ling Chin Wan received the B.Eng degree in electrical engineering and M. Eng degree in electrical from Universiti Tun Hussein Onn Malaysia (UTHM) in 2014 and 2016, respectively. Currently, he is pursuing the Ph.D. degree at the Department of Electrical and Electronic Engineering, Universiti Tun Hussein Onn Malaysia (UTHM). His current research interests include of power electronic, renewable energy, artificial intelligent and renewable energy policies.

Sim Ga Yi received his B.Eng. (Electrical Engineering) from Universiti Tun Hussien Onn Malaysia (UTHM) in 2018. She is currently pursuit Master in Universiti Tun Hussien Onn Malaysia. 